\title{
sciendo
}

Transport and Telecommunication, 2021, volume 22, no. 3, 321-331

Transport and Telecommunication Institute, Lomonosova 1, Riga, LV-1019, Latvia

DOI 10.2478/ttj-2021-0025

\section{DATA SOURCES ANALYSIS FOR SUSTAINABLE TRIP PLANNER DEVELOPMENT FOR RIGA CITY}

\author{
Alise Dinko ${ }^{1}$, Irina Yatskiv (Jackiva) ${ }^{2}$ and Evelina Budilovich (Budiloviča) ${ }^{3}$ \\ ${ }^{1,2,3}$ Transport and Telecommunication Institute \\ Lomonosova 1, LV-1019, Riga, Latvia \\ ${ }^{1}$ Alise.Dinko@gmail.com \\ 2Jackiva.I@tsi.lv \\ 3 evelina.budilovich@gmail.com
}

\begin{abstract}
In today's daily traveller world, not only the time and money became important, but climate change and pandemic raised the importance of safety and sustainability of future trip plans. In order to provide such a wide coverage for a variety of important information, a sustainable trip planner needs to receive a lot of data from a variety of differentiated data sources. Provided review of related works shows that a lot of started activities in this aspects gives all of us promises and hope that available Big Data sources will be wisely used in order to bring added value not only to individual travellers, but also society, the transportation services will become better structured and information will be easily available for smart and safe decision making, that gradually will increase life quality.

The study's main goal is analysis of open data sources for the trip planner development. Authors analysed availability of data for Riga transport system and data usage for sustainable trip planner.
\end{abstract}

Keywords: mobility, trip planner, individual preferences, open data, regulations

\section{Introduction}

Cities are home to an average of $60 \%$ of the world's and $70 \%$ of the European Union's (EU) population and generate $85 \%$ of the EU's gross domestic product. Cities have a critical role to play in achieving climate neutrality goals and transforming the economy into higher resource efficiency, while providing a quality living environment. As urbanization increases, innovative solutions are needed that promote modern, efficient and secure urban functionality, especially smart mobility and security (VARAM, 2020).

The key aim of the EU 2020 strategy was to put economies onto a high and sustainable growth path and for it Europe should use its resources in the best possible way. One of these resources is data that should be shared to promote the benefits of active mobility and be as a service for better mobility planning, monitoring and organization.

Historically traditional transportation data collection was done through surveys and census. It was very time-consuming, costly and with huge delays. In today's world, the number of built-in sensors and different mobile devices, used by the population continues to grow, together with that, is growing volume and diversity of generated data. Data becomes available on the fly.

On the other side, sustainable transportation modelling, traffic volume prediction simulations and data mining studies on passenger behaviour became sophisticated tasks for the scientists and researchers, due to the limitations of open data sources availability, ownership of the data and presence of joint structure. One of the well-known data sources is GPS and GIS (spatial) data, which can be enriched with data from personal mobile devices and public transportation cards.

The question of data sources and their availability is one of the main aspects of smart city development. The data could help to solve the accessibility and mobility issues. For this, it is necessary to define and analyse the data consequence. Moreover, the trip planners could help to organize the urban transport system existence. The main goal of a trip planner (TP) is to compile data from multiple sources to create customer oriented, safe and sustainable recommendations. The government and city authorities now and in the post-pandemic time will be looking forward to organize personal transportation, ticketing and payment methods with bigger emphasis on safety. The innovative TP creation provides opportunities to solve this problem. 
The aim of the study is to analyse different sources of information which are available for sustainable TP development, where all needed data sources would be integrated for the traveller comfort and safe journey selection, taking into account not only efficiency, but also safety and sustainability aspect of the journey.

The study methodology consists of the related works of data implementation and definition in the trip planner's analysis. Firstly, analysing approaches for transport data collections and storage for TP. Secondly, it analysing the open data availability and data structure in the Riga city case. The conclusion is covers the main problem definition and gives an overview of future research.

\section{Related works}

In today's traveller world, not only the time and money became important, but climate change and also pandemic raised the importance of safety and sustainability of future trip plans. In order to provide such a wide coverage for a variety of important information, a sustainable trip planner needs to receive a lot of data from a variety of differentiated data sources. So, one of the important question - data availability and quality. For instance, TP provides to a citizen or domestic traveller a variety of routes to choose from and the final decision is done also taking into account weather during an upcoming trip. To justify that researchers Zhou et al. in (2016) aimed to investigate the weather impacts on both public transit ridership and travel behaviour of individual transit users. Data from multiple sources were used and it provided a better foundation for the research: one-month public transport smart card transaction data for all cardholders and one-month meteorological observation data from all weather stations in Shenzhen. Additionally, data included the GPS trajectories of buses, location coordinates of all metro stations, bus stops, and weather stations and the vector maps.

The "hot" data question, such as Big Data, MaaS, Trip/journey planners, analysed by Nathanail in (2020) and Monzon and Lopez-Carreiro in (2020) is the scientific field, which covered by analysis of the availability of information and its influence on traveller behaviour.

Iliashenko et al. in the paper (2021) suggested that the biggest cities in the world are using modern technologies and velocity of available Big Data for solving transportation flow problems and needs, usually the starting point is analysis of people movement across the city, which the most accurately can be covered by mobile operator data. Next step is creation of static transportation city model, which would include traffic flows, most popular public transport stops, traffic jams etc. And here raises one of most discussed problems of transportation Big Data - what are the possibilities and limitations for transport modelling and planning with usage of static and dynamic data, such as data collected from Social Media, open data and data collected by roadside or car sensors.

As mentioned in (Leung et al., 2019) bypassing 5 years when researchers started to utilize open data and classified ground transportation modes (e.g., bus, car, bike, or walk) of commuters by analysing their GPS data, accelerometer data, and/or dwell time history. New sources of data show many unique attributes and advantages for data analytics and machine learning. For example, sensor information fusion and supervised learning of transportation data, such as traditional, sensor-based, and sensor fusion-based methods for urban data analytics and machine learning. The data sources used in the Leung et.al (2019) research were - trip traces (GNSS/GPS locations), trip accelerometer data, and GIS information. The work justifies that the combination of all data sources brings the most accurate results.

Audu in (2020) started to use real-life open data, provided by a Canadian city, which showed the effectiveness and prediction accuracy of building intelligent systems in transportation analytics and encouraging results towards the goal of developing smart cities. The system accessed open data to analyse public transport data - such as historical bus arrival time - for urban analytics; then it conducted data analytics and mining to discover patterns and based on the discovered patterns, the system was making predictions on whether the bus will arrive on time or will be late.

The variety of data sources used for smart transportation planning was described by Karami and Kashef in (2020). Researchers have used GPS and GIS data, traffic flow data sources (sensors and detectors), smart cards, mobile phone data and call detail records.

Another good example of usage of Big Data is the research (Balbin et al., 2020), where was used open Big Data of buses, operated by Winnipeg Transit (a public transit agency in the City of Winnipeg). Every bus was equipped with an on-board computer and global positioning system (GPS), which logged the on-time performance of the bus as it was leaving a bus stop.

Recent joint EU co-funded project which was devoted to urban transport system in the transition towards low carbon mobility (CITY.MULTIMODAL, 2020), brought together cities, NGOs, universities and other expert partners to facilitate the use of sustainable mobility solutions for citizens in the Baltic 
Sea Region. National, regional and city level Information and communication technologies (ICT) solutions were deeply analysed during the project. Lack of information on individual travel patterns and customer feedback on mobility applications was mentioned as one of the key informational challenges in such cities as Kalmar, Riga and Tartu. Lack of information regarding costs and benefits of mobility solutions was found in Rostock and Kalmar respectively. For all participants, GDPR (General Data Protection Regulation) and data sharing complications between platforms was a point of attention and received a set of recommendations for improvements.

Dinko et al. in (2021) analysed the TP phenomen from the data availability perspective in Riga city and suggested that doesn't exist the whole vision or strategy of the open data/ Big Data usage in the city. The data analysis is structured by the main sustainable TP features defined, that exist in the Riga TP prototypes.

Provided review shows us that a lot of started activities in this aspects gives all of us promises and hope that available Big Data sources will be wisely used in order to bring added value not only to individual travellers but also society, the transportation services will become better structured and information will be easily available for smart and safe decision making, what gradually will increase life quality.

\section{Transportation Data and Trip Planner Data Flow Overview}

With the development of information technologies transportation systems' elements started to generate different types of data with many unique attributes and advantages for its usage in sustainable TP development. Like in any other system, in the transportation system there exists a data lifecycle, which starts with the first stage, the creation of the data, presented in Figure 1.

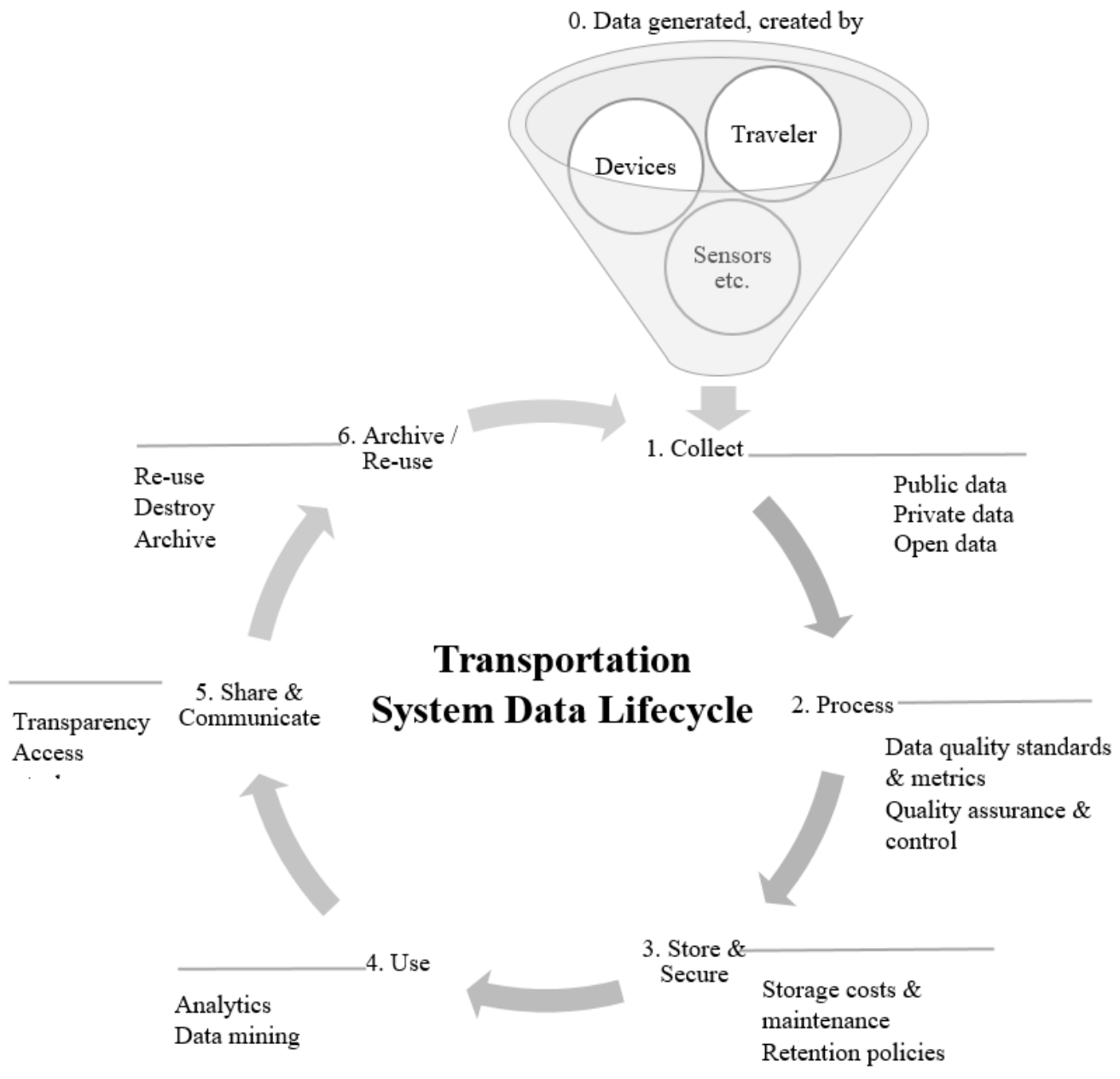

Figure 1. Transportation System Data Lifecycle 
Trip planner constantly sending requests and is getting data from different information systems, social media sources and a variety of sensors. In general, data is generated by every practical element of the transportation system, even the environment. Following stage is data collection, all the variety of differentiated data is identified and collected. Depending on data source type, there can be used different techniques for data collection. Also the ownership of the data can apply some limitations on the data usage and storage. On this stage, depending on the future need of the analysis granularity, extraction of key attributes are happening.

Processing data is the stage where data is transformed to a meaningful format, and typical errors are identified and corrected or excluded from the future analysis.

Then data should be safely stored and secured from unauthorized access. All this is related to the storage and maintenance costs, and policies, which should be followed.

Use is the stage where data is analysed, studied, different models are designed and constructed. This is the stage, where it is possible to monitor transportation systems, with aim to help understand traveller behaviour and identify ways to make the system more efficient and cost-effective.

Data sharing is the sixth stage of the transportation system data life cycle. Sharing of information and the release of information must be followed, based on relevant agreement and must be balanced against the need of data restrictions and the availability of classified and sensitive information.

The final, but not the last stage, is the archiving stage, when it is identified, which data should be moved and stored, because it is inactive at the moment and not used for any analysis, but keeping the ability to retrieve it when needed. And identify which data is still needed for analytics and should be reused.

Typically, legacy and contemporary data systems do not communicate well. Subsequently, data becomes fragmented and separated, making it difficult to access and analyse. This leads to several scenarios, where human and monetary resources are squandered.

Another area, where technology is still evolving is artificial intelligence (AI). Now, the Internet of Things, digital assistants, free text data, and video data generates droves of information. Analytic capabilities are still in their infancy, yet significant developments are emerging (DATUMIZE, 2020).

Dinko et al. in (2021) based on the sustainability approach introduced the concept of sustainable trip planner and its features. For it realization the new transportation-related data sources with different volume and velocity are required. Historically traditional transportation data collection was done through time-consuming and costly surveys and census, and with huge delays. In today's world, the number of built-in sensors and different mobile devices, used by the population, continues to grow, together with that growing volume and diversity of generated data. Data becomes available on the fly.

For understanding the concept and structure of the TP was created traveller, the sustainable trip planner with variety of data sources flows and interaction figure (see Figure 2).

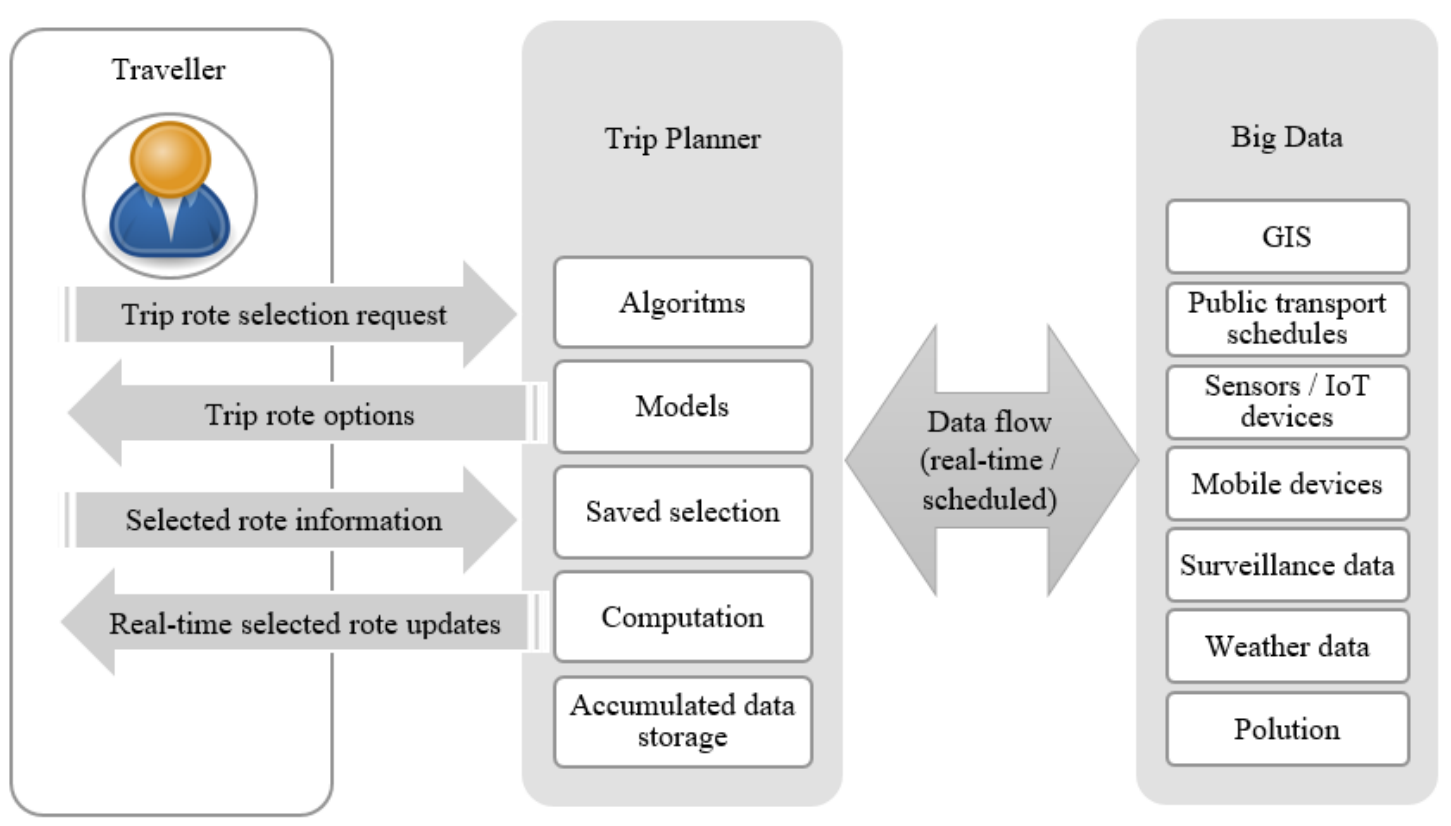

Figure 2. Traveller interaction with sustainable TP, Big Data sources, data flow, data algorithms and storage 
Sustainable TP data flow interaction (Figure 2) describes an integration of different types of data sources into a logical data flow, which transforms data into the needed information for a traveller. The main idea is that the data can be different and stored separately, but its predefined formats and access rules would allow to consolidate it for usage in the TP algorithms. We can divide data into several groups - required, available and missing or supplementary data. Available data in our case is open, which is freely available to everyone to use, without restrictions, copyrights or other mechanisms of control, see Table 1.

Table 1. Description of data types for sustainable Trip Planner

\begin{tabular}{|l|l|}
\hline Data type & Data type description \\
\hline Open data & historically stored data about weather, transport schedules and delays \\
\hline Publicly published corporate or city data & $\begin{array}{l}\text { is considered as available and it may contain as historical records, but also live } \\
\text { schedule delays information of public transport, for example }\end{array}$ \\
\hline Corporate data & $\begin{array}{l}\text { data which has limited access and typically are owned by business corporations, } \\
\text { such as data about taxi cab locations or number of available scooters and } \\
\text { supplementary information of their load }\end{array}$ \\
\hline Required data & $\begin{array}{l}\text { in the case of Sustainable TP meant data sources, that contains minimal } \\
\text { information and data required for the TP to be able to execute the algorithms for } \\
\text { providing routes choices, based on the traveller requirements. Can be map } \\
\text { information, GIS, traffic jam status or road construction work information }\end{array}$ \\
\hline Supplementary data & $\begin{array}{l}\text { is the information that is not typically present and might be needed for the specific } \\
\text { analytical researches and could be collected only based the interviews or surveys }\end{array}$ \\
\hline Survey data & $\begin{array}{l}\text { data typically not available, it should be specifically collected for the research } \\
\text { specific needs or other cases, for example traveller safety perception }\end{array}$ \\
\hline
\end{tabular}

The traveller data would not be available directly and in full volume, but would be provided based on needs and identified attributes for making proper decisions for choosing appropriate travel routes and updating with additional information based on changing travel situation and traveller profile settings.

\section{Data sources analysis for the sustainable Trip Planner in Riga}

The Riga, as capital of Latvia, is a center of commerce, industry, cultural and other economic activities. Moreover, 70\% of GPD is provided by the Riga metropole. And these aspects produce constantly increasing amount of data. Exist different data source types - open data and corporate data sources, where receiving access to the data becomes challenging or impossible, due to the regulation rules or possible commerce interests conflicts. Some have the security protection, but some under the trade secret. The authors provided analysis of the data and data sources for the TP that exist in Riga municipality, in the next sections.

\subsection{Analysis of data sources and data types for a sustainable trip planner development}

For the data availability analysis was considered the research provided by the Institute of Baltic Studies (IBS), that developed a catalogue of TP attributes to support individual travel planning applications (Veliste et al., 2019). The IBS provided the 45 main attributes with description and their availability in different applications. 40 solutions were identified while developing the attributes catalogue. All attributes were grouped by functionality type and the analysis in the Riga case was fulfilled. The analysis is visible in Table 2.

Table 2. Updated set of attributes to support individual travel planning applications (created by Veliste et al. in (2019) and adopted by paper authors)

\begin{tabular}{|l|l|c|}
\hline Functionality Group & Functionality & Riga case \\
\hline Route planning & Route optimization & $+/-$ \\
& Price optimization & - \\
& Door-to-door planning & - \\
& Door-to-door planning with via points & - \\
& Separate to-and-from planning & - \\
& Automatic planning & - \\
& Timing filters & + \\
\hline
\end{tabular}


Continuation of Table 2

\begin{tabular}{|c|c|c|}
\hline Travel information & $\begin{array}{l}\text { Live travel information } \\
\text { Real-time arrivals } \\
\text { Traffic webcams } \\
\text { Detailed public transport information } \\
\text { Station facilities information } \\
\text { Offline timetables } \\
\text { Sends a timetable } \\
\text { Next departures } \\
\text { Countdown until departure } \\
\text { Reminders } \\
\text { Number of stops }\end{array}$ & $\begin{array}{l}- \\
+ \\
+ \\
+ \\
- \\
+ \\
+ \\
+ \\
- \\
- \\
+\end{array}$ \\
\hline Navigation & $\begin{array}{l}\text { Location finder } \\
\text { Using sensors } \\
\text { Indoor navigation } \\
\text { Step-by-step directions }\end{array}$ & $\begin{array}{l}+ \\
- \\
- \\
+\end{array}$ \\
\hline Maps & $\begin{array}{l}\text { Offline maps } \\
\text { Interactive maps } \\
\text { Vehicle position } \\
\text { Compatibility with Google/Apple maps }\end{array}$ & $\begin{array}{l}+ \\
- \\
- \\
+\end{array}$ \\
\hline Travel planning & $\begin{array}{l}\text { Points of interest } \\
\text { Information about destinations } \\
\text { Sight-seeing route planner } \\
\text { Parking assistance }\end{array}$ & $\begin{array}{l} \\
- \\
? \\
-\end{array}$ \\
\hline Personalization & $\begin{array}{l}\text { Movement preferences } \\
\text { Setting preferred stops } \\
\text { Integration with address book } \\
\text { Calendar compatibility } \\
\text { Various cycling routes } \\
\text { Save a trip }\end{array}$ & $\begin{array}{l}- \\
- \\
- \\
- \\
-\end{array}$ \\
\hline Booking and payment & $\begin{array}{l}\text { Pricing info } \\
\text { Information about payment methods } \\
\text { Ticket sales points } \\
\text { Book tickets through provider } \\
\text { In-app ticket payment }\end{array}$ & $\begin{array}{l}- \\
- \\
- \\
+/- \\
+/-\end{array}$ \\
\hline Other & $\begin{array}{l}\text { Open data services } \\
\text { Crowdsourcing } \\
\text { Motivational statistics } \\
\text { Special needs } \\
\text { Customer support } \\
\text { Accessibility }\end{array}$ & $\begin{array}{l}- \\
- \\
- \\
- \\
-\end{array}$ \\
\hline
\end{tabular}

Based on the functionality grouping, we can suggest that the majority of sustainability functionality attributes fall under group -"Other". The analysis of attributes from the Riga municipality perspective shows that $75 \%$ of attributes doesn't represented in the city. About $2 \%$ of attributes - the municipality doesn't have information about data availability or information is present only partly. Only $13 \%$ of the attributes are represented or exist.

TP is one of the sustainable urban transport system element, that provides sustainable passenger transportation services. The standard EN 13 816:2002 (2002) specifies the requirement to define, target and measure the quality of service in public passenger transportation such as availability, accessibility, information, time, customer care, comfort, security and environmental impact. Dinko et al. in (2021), analysed these quality indicators features from the sustainable TP perspective. In the turn of this research, authors analysed the available transportation data, the information about data type and open data sources, owners of data, data file location, data formats, summary information about data content and frequency of data update. Table 3 describes the open data sources that it is necessary for the transportation field especially for sustainable TP creation. Data source as the Open data portal (https://data.gov.lv/) is indicated in Table 3 by code " 1 " and OpenMobilityData (http://transitfeeds.com/1/235-latvia) is indicated by code " 2 ". 
Table 3. Available open data source and transportation data for sustainable TP in Riga (data sources: https://data.gov.lv/ - 1; http://transitfeeds.com/1/235-latvia - 2)

\begin{tabular}{|c|c|c|c|c|c|c|c|}
\hline $\begin{array}{l}\text { Transportation } \\
\text { data type }\end{array}$ & $\begin{array}{l}\text { Data } \\
\text { owner }\end{array}$ & $\begin{array}{l}\text { Data } \\
\text { format }\end{array}$ & $\begin{array}{l}\text { Summary } \\
\text { information }\end{array}$ & $\begin{array}{l}\text { Update } \\
\text { frequency }\end{array}$ & $\begin{array}{l}\text { Data } \\
\text { source }\end{array}$ & Data file location & $\begin{array}{l}\text { Passenger } \\
\text { transportation } \\
\text { quality } \\
\text { indicator } \\
\end{array}$ \\
\hline $\begin{array}{l}\text { PT: route } \\
\text { information }\end{array}$ & \multirow[t]{3}{*}{$\mathrm{RS}$} & \multirow[t]{2}{*}{$\begin{array}{l}\text { Zipped } \\
\text { text } \\
\text { files }\end{array}$} & $\begin{array}{l}\text { agency.txt; stops.txt; } \\
\text { routes.txt; trips.txt; } \\
\text { stop_times.txt; } \\
\text { calendar.txt; } \\
\text { calendar_dates.txt; } \\
\text { fare_attributes.txt; } \\
\text { fare_rules.txt; } \\
\text { shapes.txt } \\
\text { frequencies.txt; } \\
\text { transfers.txt; } \\
\text { pathways.txt; } \\
\text { levels.txt; } \\
\text { feed_info.txt; } \\
\text { translations.txt; } \\
\text { attributions.txt }\end{array}$ & \multirow[t]{2}{*}{$\begin{array}{l}\text { each } \\
\text { month }\end{array}$} & \multirow[t]{2}{*}{1} & $\begin{array}{l}\text { https://developers.g } \\
\text { oogle.com/transit/g } \\
\text { tfs/reference/ }\end{array}$ & Availability \\
\hline $\begin{array}{l}\text { e-ticketing } \\
\text { validation } \\
\text { data }\end{array}$ & & & Validation data.zip & & & $\begin{array}{l}\text { https://data.gov.lv/d } \\
\text { ati/lv/dataset/e- } \\
\text { talonu-validaciju- } \\
\text { dati-rigas-satiksme- } \\
\text { sabiedriskajos- } \\
\text { transportlidzeklos/r } \\
\text { esource/7143970d- } \\
\text { 6dba-4110-bdc0- } \\
\text { 00d5797f5a39 }\end{array}$ & Availability \\
\hline PT: schedule & & & $\begin{array}{l}\text { agency.txt; } \\
\text { calendar.txt; } \\
\text { calendar_dates.txt; } \\
\text { routes.txt; shapes.txt; } \\
\text { stop_times.txt; } \\
\text { stops.txt; trips.txt }\end{array}$ & $\begin{array}{l}\text { each } \\
\text { month }\end{array}$ & 2 & & Time \\
\hline $\begin{array}{l}\text { List of } \\
\text { intercity and } \\
\text { local } \\
\text { movements } \\
\end{array}$ & \multirow[t]{3}{*}{ ATD } & \multirow[t]{2}{*}{$\begin{array}{l}\text { Zipped } \\
\text { text } \\
\text { files }\end{array}$} & & $\begin{array}{l}\text { each } \\
\text { week }\end{array}$ & \multirow[t]{3}{*}{1} & $\begin{array}{l}\text { http://www.atd.lv/si } \\
\text { tes/default/files/GT } \\
\text { FS/gtfs-latvia- } \\
\text { lv.zip }\end{array}$ & Time \\
\hline $\begin{array}{l}\text { Schedule of } \\
\text { domestic rail } \\
\text { trains }\end{array}$ & & & & $1 / 2$ year & & $\begin{array}{l}\text { https://data.gov.lv/d } \\
\text { ati/lv/dataset/ieksze } \\
\text { mes-dzelzcela- } \\
\text { vilcienu-kustibas- } \\
\text { saraksts-gtfs- } \\
\text { formata }\end{array}$ & Time \\
\hline $\begin{array}{l}\text { Stops. } \\
\text { Regional bus } \\
\text { stops }\end{array}$ & & XLSX & & daily & & $\begin{array}{l}\text { https://data.gov.lv/d } \\
\text { ati/lv/dataset/bus- } \\
\text { stop }\end{array}$ & Availability \\
\hline Routs, stops & ATD & GFTS & $\begin{array}{l}\text { agency.txt; } \\
\text { calendar.txt; } \\
\text { calendar_dates.txt; } \\
\text { fare_attributes.txt; } \\
\text { fare_rules.txt; } \\
\text { routes.txt; shapes.txt; } \\
\text { stop_times.txt; } \\
\text { stops.txt; trips.txt }\end{array}$ & daily & 2 & $\begin{array}{l}\text { http://transitfeeds.c } \\
\text { om/p/valsts-sia- } \\
\text { autotransporta- } \\
\text { direkcija/1227/lates } \\
\mathrm{t}\end{array}$ & Availability \\
\hline $\begin{array}{l}\text { Schedule of } \\
\text { domestic rail } \\
\text { trains }\end{array}$ & \multirow[t]{2}{*}{ PV } & GFTS & & $1 / 2$ year & \multirow[t]{2}{*}{1} & $\begin{array}{l}\text { https://data.gov.lv/d } \\
\text { ati/lv/dataset/dezlce } \\
\text { la-stacijas-un- } \\
\text { pieturas-punkti }\end{array}$ & Time \\
\hline $\begin{array}{l}\text { Railway } \\
\text { station stops }\end{array}$ & & XLSX & & - & & $\begin{array}{l}\text { https://data.gov.lv/d } \\
\text { ati/lv/dataset/dezlce } \\
\text { la-stacijas-un- } \\
\text { pieturas-punkti }\end{array}$ & Availability \\
\hline
\end{tabular}

The analysed data from Table 3 represent the quality indicator of transportation "Time" and "Availability" that is represented by sub-indicators: Timetable, Journey time, Expected delay, Punctuality, Network, Ticketing options and Infrastructure.

The public transport (PT) provider Riga municipal limited liability company Rigas Satiksme (RS) shares the GFTS format data in open data source portal (LR Open data portal, 2021). The information 
about timetable, journey time, stations/stops, PT agencies, routes, PT modes and schedules are compiled in Table 3. The information represents the different time periods and the actual data - the new one is about January 2021. The same PT data are stored in the open-source data portal: Open mobility data (Open mobility data, 2021). Also, RS shares actual data about e-ticket validation. The data are in the zip format and actualized monthly. All above-described data have historical periodicity. List of intercity and local transfers in GFTS format provide the authority State Ltd. Road Transport Administration (ATD). ATD shares data about bus stops, intercity and local movements, and schedules of domestic railways. All data compiled in the open source portal and have historical periodicity. Domestic railway authority Joint stock Company Pasažieru vilciens (PV) shares data of domestic passenger train schedules in GFTS format and railway stations/stops location in the XLSX format.

In sustainable approach, not only mentioned information should be provided, but also information about the environment, safety, security and accessibility for the deferent residence groups. Unfortunately, the open data regarding "Accessibility", "Customer care" and "Comfort" doesn't exist. Table 4 presents the analysis of the passenger transportation quality indicators and potential sustainable TP data that is classified under "no open data", but significant.

Table 4. Possible Data Sources for Potential sustainable TP

\begin{tabular}{|c|c|c|c|}
\hline $\begin{array}{c}\text { Passenger transportation quality } \\
\text { indicator }\end{array}$ & Data Sources & Data owner & Data format \\
\hline Time & Mobile operator data & Mobile operators & \\
\hline \multirow[t]{2}{*}{ Availability } & $\begin{array}{l}\text { Delay: GPS navigation } \\
\text { softwares }\end{array}$ & PT provider & Historical Data \\
\hline & Micromobility data & Micromobility providers & \\
\hline \multirow[t]{3}{*}{ Accessibility } & GIS data & $\mathrm{RD}$ & $\begin{array}{l}\text { *Shp, vector data } \\
\text { format }\end{array}$ \\
\hline & Mobile operator data & Mobile operators & \\
\hline & Facilities Assistance & PT provider, government & \\
\hline \multirow[t]{2}{*}{ Information } & Paratransit data (taxi) & Yandex, Bolts, others & \\
\hline & Micromobility data & Micromobility providers & \\
\hline Customer care & \multirow[b]{2}{*}{ Social media } & \multirow[b]{2}{*}{ Social media owners } & \\
\hline Comfort & & & \\
\hline \multirow[t]{2}{*}{ Safety and Security } & Video & RD, police, $\mathrm{PT}$ provider & video \\
\hline & Road safe from accident & $\begin{array}{l}\text { Police, government, insurance } \\
\text { agencies }\end{array}$ & - \\
\hline \multirow[t]{4}{*}{ Environment } & Noise & RD, LĢIA & \\
\hline & Pollution & RD, LĢIA & \\
\hline & Current Temperature & RD, LĢIA and others & \\
\hline & Weather forecasts & RD, LGIA and others & \\
\hline
\end{tabular}

RD - Riga city council, LĢIA - The Latvian Geospatial Information Agency

The "Environment" indicator is presented by the data from the Riga AIRTEXT platform (Riga airTEXT, 2021). Riga airTEXT is a free service, for the public, providing air quality alerts with SMS text message and email and has 3-day forecasts of air quality, pollen, UV and temperature. Weather forecasts, CAMS (Copernicus atmosphere monitoring service) forecasts pollution across Europe and detailed data on pollution sources across Riga are fed into the ADMS-Urban air pollution model to produce the air quality forecasts. The data on pollution sources in Riga are based on annual average emissions and do not include day-to-day variations in the emissions. The concentrations of four pollutants are calculated: nitrogen dioxide (NO2), particulates (PM10 and PM2.5) and ozone (O3). From the concentrations, the daily Air Quality Index (AQI) of each pollutant is derived. The AQI corresponds to the pollutant, which gives the highest value of the AQI this is the value shown, so the AQI shown may correspond to a different pollutant (NO2, PM10, PM2.5 or O3) on different days.

The "Security" indicator that is presented by the sub-indicator "Road safe from accident" could be presented by Google traffic and WAZE applications.

The analysis of the data availability, which was done in Table 3 and Table 4, shows that for sustainable TP development exists open and not open data sources. Open sources mostly presented by network and ticketing data. However, so necessary information for passenger transportation quality indicator as Environment, Custom care, Accessibility, Security and part of Network data doesn't represented and isn't open. 


\subsection{Open data regulations in Riga case}

The provided analysis represents that data opening and data protection need to be under strict regulation. From one side, cities need to be smart and on open data, from other side exists security and GPDR aspects that need to be taken into account. As for Riga, the city is under the Latvia Republic the ministry of development and environment (VARAM) subjection. VARAM creates the "Guidelines for digital transformation" (Guideline) (VARAM, 2020). The Guideline describes the rules for the data opening and also describes the necessity of data collection and analysis. The data goes through the innovations and smart city concept. But what does open data mean? Open data is freely available free of charge information with no re-use restrictions, that can be edited and automated using cost-free available application.

For data opening, process of digitalization or smart city creation exist laws/regulations/directives in the different spatial scope: Europe Union (EU), State level and Municipality level. The EU provides the bindings documents for the state and municipality level. The Latvia Republic main document for data digitization (VARAM, 2020) linked with the following EU development planning documents: The digital Europe program for the period 2021-2027 (EUROPEAN COMMISSION, 2018), Connectivity for a Competitive Digital Single Market - Towards a European Gigabit Society (EUROPEAN COMMISSION, 2016), directive 2014/61/EU on measures to reduce the cost of deploying high-speed electronic communications networks (Official Journal of the European Union, 2014), Pamatnostādnes Vienotās digitālās vārtejas regulas īstenošanai (Eiropas Savienības Oficiālais Vēstnesis, 2019), First Progress Report on the EU Security Union Strategy (EUROPEAN COMMISSION, 2020), European e-Justice Strategy (2019-2023) (Official Journal of the European Union, 2019a), EU directive 2019/1024 of the open data and re-use of public sector information (Official Journal of the European Union, 2019b), European Interoperability Framework (EIF) (EUROPEAN COMMISSION, 2017) and others.

The Guidelines (2020) suggested that in line with increasing urbanization, the importance of smart mobility is gaining increasing global recognition by promoting innovative solutions to improve overall mobility in the urban environment. Smart mobility covers a wide range of solutions, including autonomy (cars, aircraft/drones, water vehicles), development of smart infrastructure (smart traffic lights, vision solutions, smart parking), as well as the development of digital infrastructure (data acquisition, open access, cybersecurity, communication network provision). It is important to emphasize that smart mobility solutions depend on the most interconnected elements, so it is not effective to distinguish the development of a single solution, such as one of stand-alone solutions.

Besides, the OECD provided a detailed analysis of the results for each OECD member and partner countries by comparing the results for 2019 (OECD, 2020) with those of the 2017 edition on the digital transformation of the public sector, including digital government and data-driven public sector and open government data was suggested that Latvia was ranked (by the DESI index) in the field of digital technology integration on 23rd place among EU countries. Latvian companies do not make full use of the opportunities provided by large data and cloud computing and such share of Latvian companies remains unchanged. Only $8 \%$ of companies use Big Data (EU average 12\%) and $11 \%$ use cloud computing (EU average $18 \%$ ).

The Latvia Republic the Cabinet of Ministers developed the Regulations No. 445 REGULATION OF OPEN DATA IN LATVIA July 14, 2020, "Procedure for Posting Information on the Internet by Institutions" (Regulation). The Regulation says that the authority must have open data in machinereadable form, together with metadata, or only metadata of the dataset is published on the Latvian Open Data Portal (LR Open data portal, 2021). The open data portal is a national information system, operated by the Ministry of the Environment and Regional Development (hereinafter referred to as the Manager) and the holder State Agency for Regional Development.

\subsection{Recommendations}

The provided analysis shows that there exists a problem of data management. The municipality has a complicated structure with departments and municipality companies. There is not existing data strategy of how to collect, organize and open data. For example, the mobility data are collected by the following equipment: the cameras, in public spaces (owner the police); the smart light signals, in some crossroads (owner Riga city council Traffic department (RD SD)), velo(cyclist) and pedestrian counter (RD SD); data of passenger tickets validation into public transport (RS); information from station for pollution detecting (RD MVD) and others.

As presented in the research, for the data management exists the amount of declarations and regulations in local, national and EU levels. 
The municipality needs to understand what kind of data they have, in what format and actual this data. The amount of regulations and directives provided doesn't work when the municipality doesn't have the data management road map. The trip planner development is the chance for the municipalities to put in order the data generated. Data digitization and standardization is the perspective of the cities to be smart and convenient to the citizens.

\section{Conclusions}

These days open data initiatives make significant progress and give a lot of possibilities for using available resources to develop sustainable traveller-oriented trip planning tool, that attract more users and will provide to passengers easy access to information in a short time from any location. A sustainable trip planner will attract more customers for the public transportation, informing the travellers regarding possible faster, safer, more comfortable, including environmental aspects, and cheaper alternatives of route.

The cities, government and other authorities provide tremendous efforts to the data management organization in a sustainable way. The TP development could be a good example for this solution implementation. Creation of the smart city concept or guidelines, could be a solution for data management.

However, the analysis of the provided information of the sustainable TP creation in Riga case showed big challenges and problems:

- the regulation for the data prohibition;

- the regulation for the private data using;

- local regulations of the video data collection;

- the data owners would not open and share the data because of the trade secrete;

- failure of data standardization and digitalization;

- legal uncertainty of civil liability in cases of damage caused by artificial intelligence or other autonomous means. creation

Future research could be conducted for the framework created for the sustainable trip planner

\section{References}

1. Audu, AR.A., Cuzzocrea, A., Leung, C.K., MacLeod, K.A., Ohin, N.I., Pulgar-Vidal, N.C., (2020) An Intelligent Predictive Analytics System for Transportation Analytics on Open Data Towards the Development of a Smart City. Complex, Intelligent, and Software Intensive Systems. CISIS 2019: Advances in Intelligent Systems and Computing, 993. Springer, Cham: https://doi.org/10.1007/9783-030-22354-0_21.

2. Balbin, P., Barker, J., Leung, C.K, Tran, M., Wall, R., Cuzzocrea, A. (2020) Predictive analytics on open big data for supporting smart transportation services. In: Procedia Computer Science, 176, https://www.sciencedirect.com/science/article/pii/S1877050920321049.

3. CITY.MULTIMODAL (2020) Project Cities-multimodal. https://www.cities-multimodal.eu/about: INTERREG Baltic Sea Region Programme 2014-2020.

4. DATUMIZE, 2020. The 5 challenges travel companies must overcome to extract value from data. Barcelona, Spain: https://www.datumize.com/.

5. Dinko, A., Yatskiv (Jackiva), I., Budiloviča (Budilovich), E. (2021) Trip Planner Challenges in the Era of Fast Changing Requirements. Reliability and Statistics in Transportation and Communication, https://doi.org/10.1007/978-3-030-68476-1 45

6. Eiropas Savienības Oficiālais Vēstnesis (2019) Pamatnostā̄̄nes Vienotās digitālās vārtejas regulas istenošanai 2019.-2020. gada darba programma. Komisijas pazinojums: https://eurlex.europa.eu/legal-content/LV/TXT/HTML/?uri=CELEX:52019XC0731(01)\&from=EN.

7. EUROPEAN COMMISSION (2016) Connectivity for a Competitive Digital Single Market - Towards a European Gigabit Society. Brussels: 14.9.2016: COM(2016) 587 final..

8. EUROPEAN COMMISSION (2017) European Interoperability Framework - Implementation Strategy. In: Communication from the commission to the european parliament, the council, the european economic and social committee and the committee of the regions: https://eurlex.europa.eu/resource.html?uri=cellar:2c2f2554-0faf-11e7-8a35-01aa75ed71a1.0017.02/DOC_1\&f.

9. EUROPEAN COMMISSION (2018) Regulation of the european parlament and of the council establishing. The digital europe programme for the period 2021-2027. Brussels: COM(2018) 434. 
10. EUROPEAN COMMISSION (2020) First Progress Report on the EU Security Union Strategy. Brussels: https://ec.europa.eu/info/sites/info/files/communication_on_the_first_progress_report_on_the_eu_se curity union_strategy.pdf..

11. Iliashenko, O., Iliashenko, V., Lukyanchenko, E. (2021) Big Data in Transport Modelling and Planning. In: Transportation Research Procedia, 54, 900-908, ISSN 2352-1465, https://doi.org/10.1016/j.trpro.2021.02.145).

12. Karami, Z., Kashef, R. (2020) Smart transportation planning: Data, models, and algorithms. Transportation Engineering, 2, https://www.sciencedirect.com/science/article/pii/S2666691X20300142.

13. Leung, C.K., Braun, P., Cuzzocrea, A. (2019) AI-Based Sensor Information Fusion for Supporting Deep Supervised Learning. Sensors 19, 6, 1345.

14. LR Open data portal, 2021. data.gov.lv. [Online] Available at: https://data.gov.lv/dati/eng/dataset?groups=transports\&organization=rigas-satiksme

15. Monzon, A., Lopez-Carreiro, I. (2020) Key factors influencing MaaS adoption in EU metropolitan areas: comparison between Randstad (Netherlands) and Madrid. Reliability and Statistics in Transportation and Communication. Selected Papers from the 20th International Conference on Reliability and Statistics in Transportation and Communication, RelStat 2020, 14-17 October 2020, Riga, Latvia. https://doi.org/10.1007/978-3-030-68476-1:

16. Nathanail, E. (2020) THE INFLUENCE OF INFORMATION ON MOBILITY BEHAVIOR AND CHOICES. Reliability and Statistics in Transportation and Communication. Selected Papers from the 20th International Conference on Reliability and Statistics in Transportation and Communication, RelStat 2020, 14-17 October 2020, Riga, Latvia. https://doi.org/10.1007/978-3-030-68476-1

17. OECD (2020) Open, Useful and Re-usable data (OURdata Index): Results for 2019 and 2017. EU: http://www.oecd.org/gov/digital-government/ourdata-index-policy-paper-2020.pdf.

18. Official Journal of the European Union, 2014. Directive 2014/61/EU of the European Parliament and of the Council of 15 May 2014 on measures to reduce the cost of deploying high-speed electronic communications networks. The European Parliament and the Council of the European Union: https://eur-lex.europa.eu/legal-content/en/TXT/?uri=celex\%3A32014L0061.

19. Official Journal of the European Union, 2019a. 2019-2023 Strategy on e-Justice. NOTICES FROM EUROPEAN UNION INSTITUTIONS, BODIES, OFFICES AND AGENCIES: https://eurlex.europa.eu/legal-content/EN/TXT/PDF/?uri=CELEX:52019XG0313(01)\&rid=7.

20. Official Journal of the European Union, 2019b. Directive (EU) 2019/1024 of the European Parliament and of the Council of 20 June 2019 on open data and the re-use of public sector information. PE/28/2019/REV/1: https://eur-lex.europa.eu/legal-content/EN/TXT/?uri=CELEX\%3A32019L1024.

21. STANDARD (2002) European Standard: EN 13 816:2002. EU: http://standards.cen.eu/dyn/www/f?p=204\%3A110\%3A0\%3A\%3A\%3A\%3AFSP_PROJECT\%2CF SP_O....

22. VĀRAM (2020) Digitālās transformācijas pamatnostādnes. In: 14. LR VARAM, Projekts: https://www.varam.gov.lv/sites/varam/files/content/files/digitalas-transformacijas-pamatnostadnes2021-27.pdf..

23. Veliste, M., Henahan, R., Käger, M., Tatar, M. (2019) Multimodal travel planning - An analysis of ICT travel planning solutions in Baltic Sea Region cities. s.l.:cities.multimodal.

24. Zhou, M., Wang, D., Li, Q., Yue, Y., Tu, W., Cao, R. (2016) Impacts of weather on public transport ridership: Results from mining data from different sources. Transportation Research Part C: Emerging Technologies, 75, 17-29, 2017. ISSN 0968-090: https://doi.org/10.1016/j.trc.2016.12.001. 